\title{
Status of the Development of Renewable Energy Projects in the Republic of Panama
}

\author{
A. Sebastiano Giardinella ${ }^{1}$, B. Alberto Baumeister ${ }^{1}$, C. Ysmael Da Silva ${ }^{1}$ \\ ${ }^{1}$ INELECTRA A PETROTIGER COMPANY \\ Ave. La Rotonda. Business Park. Torre Este. Piso 5. Costa del Este. Panama City. Panama. \\ Phone/Fax number:+507 3404800/+507 3404801, e-mail: sebastiano.giardinella@inelectra.com, \\ alberto.baumeister@inelectra.com, and ysmael.dasilva@inelectra.com
}

\begin{abstract}
The Republic of Panama plans to expand its power generation park by including renewable energy. Currently, more than half of the Panamanian power generation park is comprised of hydroelectric power and the rest is completed by thermoelectric plants, but other energy sources such as wind, solar, geothermal and peat are available. This paper reviews the current status of the Panamanian power generation park, recent renewable energy developments, the legal framework and incentives in place for these projects, and the renewable energy resources available in the country. Finally, some hypothetical renewable energy projects are evaluated, to initially assess their economic feasibility. It can be concluded from this paper that: 1) hydro power is the only renewable currently in the Panamanian power generation park and comprises most of the future projects, 2) wind power is the other renewable with most potential in Panama, with the second-largest number of projects, 3) solar, geothermal and peat resources are available in Panama but there are no current developments to include them as part of large-scale power generation, 4) initial evaluation of two hypothetical hydroelectric and wind projects shows economic feasibility under the given assumptions; however, the project feasibility is dependent on specific site conditions.
\end{abstract}

\section{Key words}

Panama renewable power generation

\section{Introduction}

The Republic of Panama is located in Central America, with borders to the North with the Caribbean Sea, to the South with the Pacific Ocean, to the East with Colombia and to the West with Costa Rica. It has a population of $3,322,576$ inhabitants, according to the 2010 census, over $70 \%$ of them living in urban areas.

Panama has, since recent years, been subject to appreciable economic growth fuelled by extensive public investment in large infrastructure projects, such as the construction of new highways, the expansion of Panama City's coastal line or the Panama Canal Expansion megaproject; and large private investment in the areas of real-estate, tourism, banking, among others, and particularly in the energy and power sector.

Panama has been traditionally dependent on hydro and thermal power for the supply of its energy demand, but recent private developments have begun to make use of the country's other natural resources, such as wind, in conjunction with the government's plan to reduce its dependency on imported hydrocarbons, as well as make the current energy grid more efficient. As of 01/05/2010, the Environment National Authority (Autoridad Nacional del Ambiente, ANAM) had 118 Clean Development Mechanism (CDM) projects within its portfolio, most of which from the private sector.

The purpose of this article is to describe the current status of the power generation park in the Republic of Panama and future expansion plans, as well as describe the current renewable energy developments, legislation and incentives, available resources, and present sample hypothetical case studies for individual renewable power generation projects in the country.

\section{Electrical Power Generation Park in Panama}

\section{A. Current Status}

By the year of 2008, the installed electrical power capacity of the Panamanian National Interconnected System (Sistema Interconectado Nacional, SIN) was 1,501 MW, whereas the maximum demand (excluding self-generating consumers) was 1,065 MW [1].

The power generation sector in Panama is comprised of several independent producers, with three companies providing approximately $70 \%$ of the power generation capacity: AES Panamá (33\%); EGE-Fortuna, S.A. (20\%) and BLM Corp, S.A. 55\% of the Panamanian generation park capacity comes from hydroelectric plants and $45 \%$ from thermoelectric plants. The composition of the power generation park is shown on Figure 1.

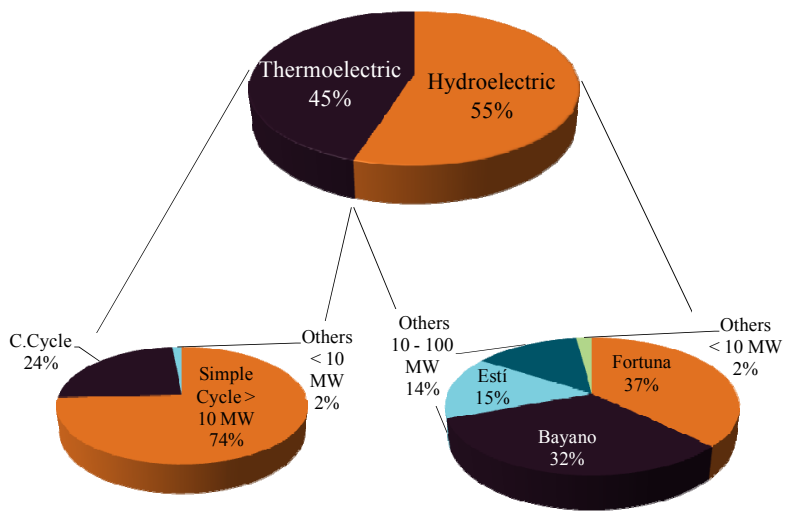

Fig. 1. Panama SIN Power Generation Park Composition (Source data from [1])

The hydroelectric power generation park is comprised of several dams, three of which account for $86 \%$ of the total installed hydroelectric capacity: Fortuna (300 MW - 
37\%), Bayano (260 MW - 32\%) and Estí (120 MW $15 \%)[1]$.

The thermoelectric power generation park is comprised mostly of simple cycle turbines operating either on bunker fuel, marine diesel or light diesel, which account for $76 \%$ of the installed thermoelectric capacity, and one combined cycle fuelled by marine diesel. The average heat rate (weighed on installed capacity) for the Panamanian thermoelectric power generation park is approximately $10,400 \mathrm{BTU} / \mathrm{kWh}$, or an equivalent $33 \%$ efficiency, based on higher heating value (source: own estimations, based on fuel consumption in USgallons/MWh from Reference [1]).

\section{B. 2009-2023 Expansion Plan}

The projections for growth of energy demand in Panama in the period of 2009 to 2023 involve three scenarios: low, medium and high demand with projected loads of $1.85 \mathrm{GW}, 1.88 \mathrm{GW}$ and $1.96 \mathrm{GW}$ in the year of 2023 , respectively [1].

The Panamanian Empresa de Transmisión Eléctrica S.A. (ETESA) expansion plan will include ongoing and future projects in both existing energy conversion processes in the country, such as hydroelectric power and liquidfuelled thermal power plants, and new energy sources such as wind power, natural gas and coal. In wind power alone there are twenty-nine (29) projects with provisional licenses for a total of $4.4 \mathrm{GW}$, but only three (3) of them showed significant progress [1].

Table I shows the number of most-likely candidate projects for future construction and startup in Panama, along with the total installed capacity and average construction cost, according to the ETESA expansion plan.

Table I. - Potential Panamanian Power Generation Projects

\begin{tabular}{|l|c|c|c|}
\hline Category & $\begin{array}{c}\text { Potential } \\
\text { Projects }\end{array}$ & $\begin{array}{c}\text { Installed } \\
\text { Capacity } \\
\text { MW }\end{array}$ & $\begin{array}{c}\text { Average } \\
\text { Investment } \\
\text { Cost USD/kW }\end{array}$ \\
\hline Wind Power & 4 & 474 & 1,549 \\
\hline Hydroelectric Power & 23 & 1,022 & 2,241 \\
\hline $\begin{array}{l}\text { Thermal - Medium-Speed } \\
\text { Motor - Liquid Fuel }\end{array}$ & 2 & 150 & 1,333 \\
\hline $\begin{array}{l}\text { Thermal - Combined Cycle - } \\
\text { Natural Gas }\end{array}$ & 3 & 500 & 1,250 \\
\hline $\begin{array}{l}\text { Thermal - Combined Cycle - } \\
\text { Diesel }\end{array}$ & 2 & 400 & 1,238 \\
\hline Thermal - Gas Turbine & 2 & 150 & 833 \\
\hline Thermal - Diesel Turbine & 1 & 100 & 930 \\
\hline $\begin{array}{l}\text { Thermal - Coal Steam Cycle } \\
\text { Thermal - Steam Cycle }\end{array}$ & 2 & 400 & 1,800 \\
\hline TOTAL & $\mathbf{4 0}$ & 130 & 569 \\
\hline
\end{tabular}

As can be seen, the future installed capacity, if all of the potential projects are completed, will widely exceed the country's local energy demand. It is within the government's objectives to promote Panama as an energetic centre for the Americas, and it is currently developing plans to expand the existing transmission lines and construct new interconnecting lines between the Central American Nation and its neighbors, such as Colombia, in order to export excess energy.

\section{Clean Development Mechanism (CDM) Projects in Panama}

\section{A. Current CDM Portfolio}

Following the incentives set upon the Kyoto Protocol for carbon emission reduction (CER) projects, both private and government entities have sponsored an appreciable number of CDM developments in recent years, in the areas of: hydroelectric power, wind power, energy efficiency, energy from biomass, methane capture, transportation and reforestation.

At the date of $01 / 05 / 2010$, the number of registered CDM projects in Panama totalled 118, with approximate CERs of $44.5 \times 10^{12}$ equivalent tonnes of $\mathrm{CO}_{2} /$ year, according to the ANAM [2]. The CDM project breakdown by number of projects, and CERs by project type are given on Figure 2.

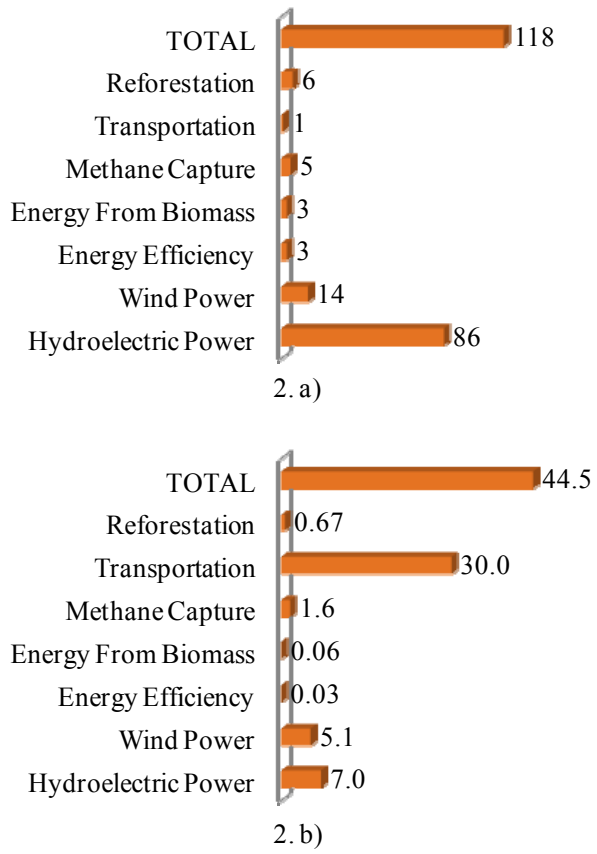

Fig. 2. Panama CDM Portfolio Breakdown. 2.a) By number of projects, 2. b) By CERs/year ( $10^{12}$ tonnes eq. $\left.\mathrm{CO}_{2}\right)$

As can be seen on Figure 2, the vast majority of registered CDM projects in Panama are for hydroelectric power generation, followed by wind power generation. On the other hand, the largest carbon emission reduction comes from one transportation project: the Panama Canal Expansion, which accounts for $30 \times 10^{12}$ equivalent tonnes of $\mathrm{CO}_{2} /$ year.

A small number of projects were focused on substituting traditional energy sources for biomass, but up to $01 / 05 / 2010$ there were no solar or geothermal power generation projects in the CDM portfolio. 


\section{Legal Framework and Incentives for the Development of Renewable Energy Projects in Panama}

\section{A. General Electric Sector Legal Framework}

Law No.6 of February $3^{\text {rd }} 1997$, with modifications from law-decree No.10 of February $26^{\text {th }} 1998$, establishes the institutional and regulatory framework for the electric utility sector in the Republic of Panama. The main aspects of this law are the establishment of:

1) the entity in charge of determining the state policies and review the preparation of expansion plans in the electric sector,

2) regulations for the creation and operation of public electric companies,

3 ) the modalities for participation of private companies in the electric sector,

4) the structure of the Panamanian electric sector,

5) dispositions pertaining to the tariffs, customers of the electric sector, acquisition of real-estate and utilities,

6) sanctions, and

7) final dispositions pertaining to the conservation of the environment, promotion of renewable or nonconventional sources and energy conservation.

The dispositions for the participation of national, foreign or mixed capital companies in the Panamanian electric sector are given in Title II, Chapter V. Private participation can be in three modalities [3]: 1) buying shares of State-owned electric companies, 2) concessions, or 3 ) licences.

The buying of shares was regulated, as per this law, in blocks of over $51 \%$ of State-owned thermoelectric generation and distribution companies, or up to $49 \%$ of hydroelectric generation companies.

The construction and operation of hydroelectric and geothermal power generation, as well as power transmission and distribution are subject to concessions no longer than 50 years for hydroelectric and geothermal power generation, and 25 years for power transmission and distribution, which can be extended in terms no longer than the original concession.

The construction and operation of power generation plants of different types to those subject to concessions are subject to licenses. The terms of each license are determined on a case-by-case basis.

\section{B. Renewable Energy Incentives}

The basis for the promotion of renewable energy is given on Title VIII, Chapter II of Law No.6 of February $3^{\text {rd }}$ 1997. As a first incentive, the power transmission company is required to give a five percent $(5 \%)$ preference in the evaluated price to new and renewable energy sources in each tender to purchase energy and power. The distribution companies are required to give the same preference when performing direct purchases
[3]. The new and renewable energy sources are defined in this law as: geothermal, wind, solar, waste-to-power and hydroelectric, the latter limited to $3 \mathrm{MW}$ of continuous power in the average hydrological year.

Further incentives for renewable energy developments are established in Law $\mathrm{N}^{\circ} 45$ of August $4^{\text {th }} 2004$, which include the following [4]:

1) New and renewable energy sources, as well as minihydroelectric power plants up to $10 \mathrm{MW}$ installed capacity are not subject to distribution or transmission charges when selling directly or occasionally,

2) new and renewable energy sources, as well as minihydroelectric power plants in the range of 10 to $20 \mathrm{MW}$ installed capacity are not subject to distribution or transmission charges for the first $10 \mathrm{MW}$ of installed capacity for the first 10 years of commercial operation,

3) exemption of taxes on all imports of equipment, machinery, materials, or others required for construction, operation and maintenance of particular new and renewable energy power plants of up to $500 \mathrm{~kW}$ installed capacity,

4) fiscal incentive for new and renewable energy projects up to $10 \mathrm{MW}$ installed capacity, equivalent up to twentyfive percent $(25 \%)$ of direct investment, based on equivalent tonnes of $\mathrm{CO}_{2}$ emission reductions per year calculated for the term of the license or concession, which can be used for payment of revenue tax (Impuesto Sobre la Renta) during the first 10 years of commercial operation, as long as the project is not benefitting from other incentives.

5) fiscal incentive for new and renewable energy projects over $10 \mathrm{MW}$ installed capacity, equivalent up to twentyfive percent $(25 \%)$ of direct investment, based on equivalent tonnes of $\mathrm{CO}_{2}$ emission reductions per year calculated for the term of the license or concession, which can only be used for payment of up to fifty percent $(50 \%)$ of the revenue tax (Impuesto Sobre la Renta) during the first 10 years of commercial operation, as long as the project is not benefitting from other incentives.

6) fiscal credit applicable to the revenue tax (Impuesto Sobre la Renta) for a maximum of five percent $(5 \%)$ of direct investment in works that would later on become public-use infrastructure, such as roads, bridges or other.

The amount of incentives given as result of greenhouse gas emission reductions will be based on a reference price per equivalent tonne of $\mathrm{CO}_{2}$ per year and a baseline in equivalent tonnes of $\mathrm{CO}_{2}$ per year per MW-hour, and is applicable if the generating company does not gain benefits from $\mathrm{CO}_{2}$ trading.

The baseline emission factors and reference price for the calculation of incentives to new, clean and renewable energy projects are specified on Resolution $\mathrm{AN} \mathrm{N}^{\circ} 2700$ Elec of June $24^{\text {th }} 2009$.

The baseline in tonnes of equivalent $\mathrm{CO} 2$ per $\mathrm{MWh}$ is according to Table II.

The reference price per tonne of equivalent $\mathrm{CO}_{2}$ is calculated for each project based on the average of the 
series of the 12 months of the year in which the power generation facility which is subject of the license or concession enters operation, using the data from Thomson Reuters Carbon Community. By the date of the resolution, the reference price per tonne of equivalent $\mathrm{CO}_{2}$ for the year 2009 was set at 24.02 US dollars, solely for the calculation of incentives according to Law No. 45 of 2004.

Table II. - Baseline Emission Factors [5]

\begin{tabular}{|l|c|c|c|}
\hline \multirow{2}{*}{ Type of Project } & \multicolumn{3}{|c|}{ Credit Periods } \\
\cline { 2 - 4 } & $\begin{array}{c}\text { First Period } \\
\mathbf{2 0 0 8 - 2 0 1 4}\end{array}$ & $\begin{array}{c}\text { Second } \\
\text { Period } \\
\mathbf{2 0 1 5 - 2 0 2 1}\end{array}$ & $\begin{array}{c}\text { Third Period } \\
\mathbf{2 0 2 2 - 2 0 2 8}\end{array}$ \\
\hline Wind and Solar & 0.673 & 0.673 & 0.673 \\
\hline & 0.568 & 0.462 & 0.462 \\
\hline
\end{tabular}

\section{Available Natural Energy Resources in Panama}

As the result of several studies in the last decade, a potential for power generation has been identified in Panama, in the following resources: hydro energy, wind energy, solar energy and peat.

\section{A. Hydro Energy}

As can be seen on Figure 2, the vast majority of renewable power generation projects are of the hydro power type. The hydroelectric power potential is one of the better characterized, with a hydroelectric study catalogue comprising approximately 180 projects including better handling schemes of existing reserves, as well as medium, mini and micro projects, which represent an available inventoried hydro potential of 3040.27 MW [1]. The three provinces with the highest hydro power potential in Panamá are Bocas del Toro, Chiriquí and Veraguas, as can be seen on Figure 3.

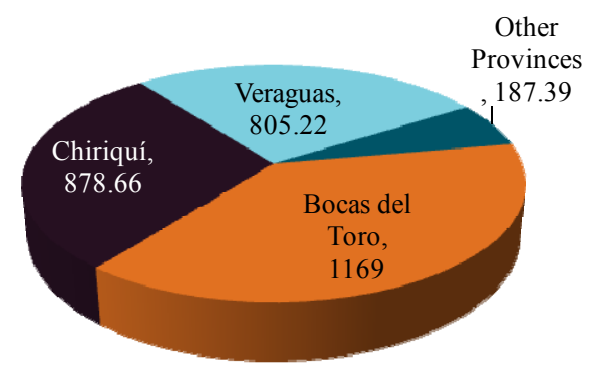

Fig. 3. Hydro Power Potential (MW) per Province

Out of the 3040.27 MW, 2010.21 MW are currently in projects in different stages of pre-feasibility, feasibility and design, and 1030.06 MW are in survey level.

\section{B. Solar Energy}

Upon review of the Solar and Wind Energy Resource Assessment (SWERA) data, the annual average amount of solar resource available to tilted and horizontal flat- plate collectors is between 4.0 and $6.0 \mathrm{kWh} / \mathrm{m}^{2} /$ day in most of the Panamanian territory. Figure 4 shows the annual average solar radiation that can be used by tilted flat-plate collectors. The solar radiation that can be used by a horizontal flat-plate collector is essentially the same as shown on Figure 4, since the country is located in the tropics.

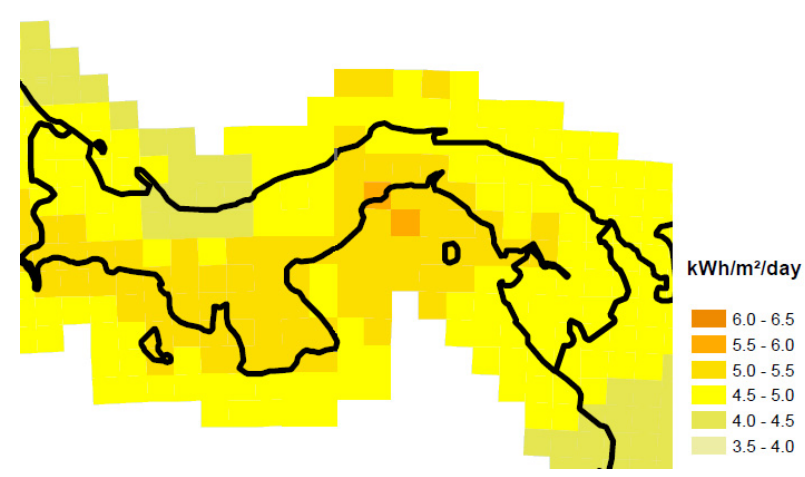

Fig. 4. Panama Annual Average Flat Plate Tilted at Latitude Solar Map. Adapted from [6]

The use of solar PV collectors in Panama has traditionally been limited to small communities or farms with no access to electricity, as alternative to diesel generators.

On the other hand, the potential for concentrating solar applications in Panama is very limited, since the direct normal annual average solar radiation is lower than 3 $\mathrm{kWh} / \mathrm{m}^{2} /$ day in most of the Panamanian territory.

\section{Wind Energy}

The S-shape of Panama makes it a favourable spot for wind energy development, since the entire length of its Caribbean coast is exposed to the trade winds. Also, the Panamanian climate makes wind power a potential complement to hydro power, since the wind intensity is highest during the drought months, when hydro power potential is at its lowest.

A study by ETESA, UNDP and Lahmeyer International generated the Panama wind resource map shown on Figure 5. As can be seen on Figure 5, the highest wind power potential (shown on the blue areas) are certain places of the Central Cordillera, such as Cerro Tute, the eastern coast of Los Santos, the Caribbean coastline of Bocas del Toro, Colón and Veraguas, and the Las Perlas archipelago, with average annual wind speeds of over 7 meters per second at 40 meters above ground level. It is precisely in the areas of the Central Cordillera, and Los Santos coast where current wind power developments are located.

\section{Geothermal}

The potential for geothermal power in Panama has been studied in several occasions since the 1970's, and five (5) main areas for potential geothermal power generation have been evaluated since: Barú-Colorado, Valle de 


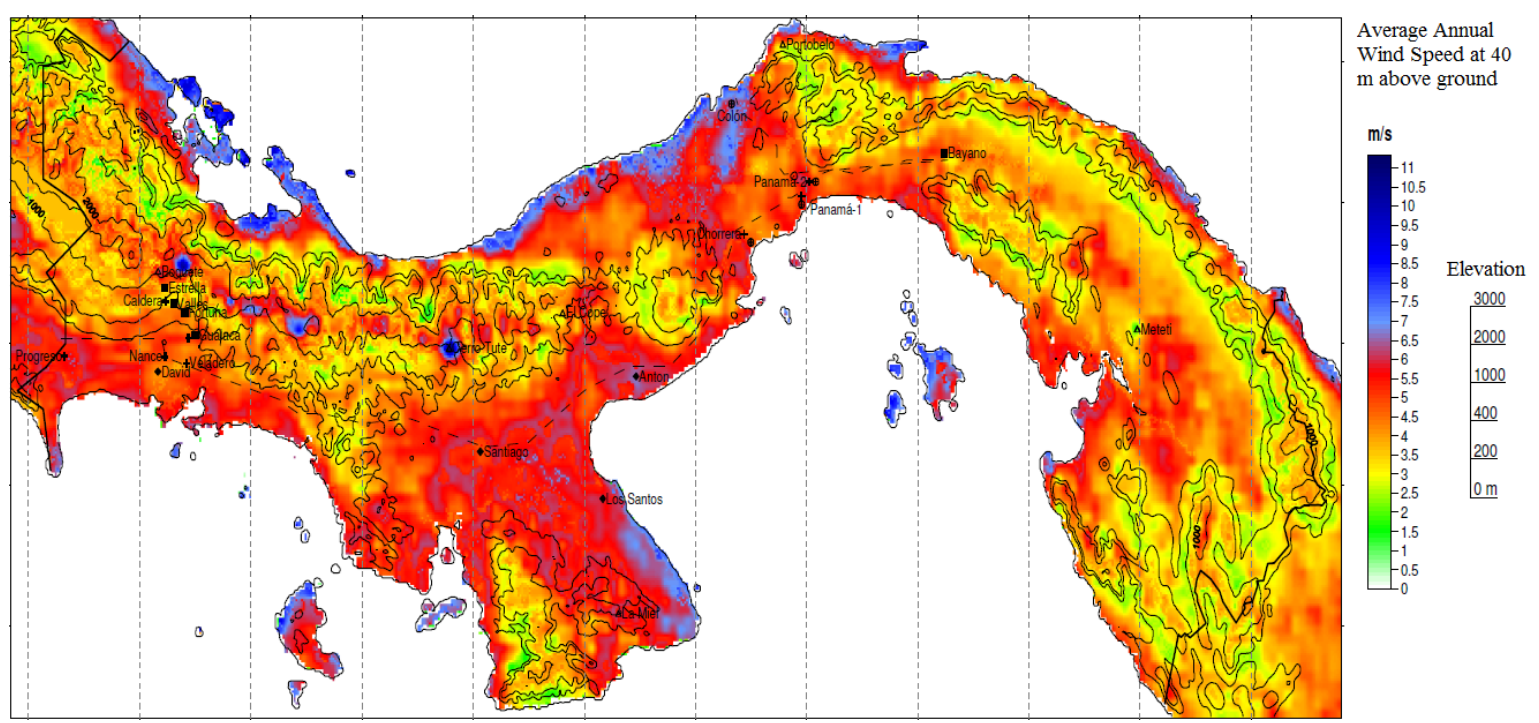

Figure 5. Average Annual Wind Speed at $40 \mathrm{~m}$ Above Ground Level. Adapted from [7]

Antón, Coiba Island, Tonosí and Chitre de Calobre. The different studies varied in conclusions, placing the entire geothermal potential for Panama between $100 \mathrm{MW}$ and $450 \mathrm{MW}$. A more recent evaluation from the firm West Japan Engineering Consultants, Inc., estimated the geothermal potential for the Barú-Colorado area at 24 MW and for the Valle de Antón area at 18 MW [8]. Since then, private companies have shown little interest in geothermal power generation.

\section{E. Peat}

Even though peat is not a renewable energy source (it is classified as intermediate), it can nonetheless be considered a potential alternative to imported hydrocarbon and coal fuels.

A study financed by the Agency for International Development (AID) identified a large deposit of goodquality and potentially usable peat, located at the Northwest of Panama, near Changuinola. The amount of usable peat resource was estimated at around 118 million tonnes with $35 \%$ humidity, or enough to supply fuel for a 30 MW power plant for a period of over 30 years [9]. The Changuinola peat characterization is shown on Table III.

Very limited information is available after said study, as private companies have shown little interest in exploiting the peat resource in Panama.

\section{Hypothetical Case Studies for Renewable Power Generation in Panama}

In this section, different hypothetical renewable power generation projects are evaluated in order to show how the information contained in this paper could be used to initially assess economic viability using open software such as RETScreen4-1 (2010-09-22 release) from RETScreen ${ }^{\circledR}$ International, and identify the impact of Panamanian government incentives on the project cashflow. The types of projects and capacities considered are based on the currently proposed future projects.
Table III. - Changuinola Peat Characterization [9]

\begin{tabular}{|l|c|}
\hline Volatile matter & $62 \%$ (dry weight average) \\
\hline Ash & $4 \%$ (dry weight average) \\
\hline Organic matter & $96 \%$ (dry weight average) \\
\hline Humidity & $85-95 \%$ (approximate variation) \\
\hline Heating value & $10,000 \mathrm{BTU} / \mathrm{lb}$ (dry average) \\
& $8,824-11,310 \mathrm{BTU} / \mathrm{lb}$ (variation) \\
\hline $\mathrm{pH}$ & $3.5-4.8($ approximate variation) \\
\hline Density & $0.1 \mathrm{~g}^{3} \mathrm{~cm}^{3}$ (approximate) \\
\hline Absorbance & $1400 \%-2400 \%$ (approximate) \\
\hline & $2270^{\circ} \mathrm{F}$ (initial, reducing) \\
Ash fusion temperature & $2310^{\circ} \mathrm{F}$ (initial, oxidizing) \\
& $2640^{\circ} \mathrm{F}$ (fluid, reducing) \\
& $2670^{\circ} \mathrm{F}$ (fluid, oxidizing) \\
\hline
\end{tabular}

These evaluations should be considered as very rough estimates of potential returns from renewable power generation projects in Panama, and not as thorough evaluations, given that accurate cash-flow analysis is dependent on site-specific conditions, such as capacity factor, availability of land, access roads, distance to transmission lines, environmental impacts, among others specific to each potential site.

\section{A. Methodology and Assumptions}

Two renewable power generation technologies (hydroelectric and wind) were evaluated using RETScreen4-1 with the general assumptions given on Table IV, to estimate the pre-tax internal rate of return. Following this, the tax was calculated taking into account the incentives on section 4-B of this paper and the posttax internal rate of return was estimated. Inflation and carbon trading were not considered in the evaluation.

Geothermal and peat-fuelled power generation are not evaluated due to lack of data in the consulted literature, which is required to estimate the resource extraction costs (in the case of geothermal, data related to the wells, and in the case of peat, data required to estimate peat mining). Solar power generation was studied in [10] for houses and commercial buildings and was not found to 
be a competitive alternative to grid electricity where the electric grid is available.

Table IV. - General Assumptions

\begin{tabular}{|l|c|}
\hline Contracted energy price & $72.55 \mathrm{USD} / \mathrm{MWh}$ (Note 1) \\
\hline Contracted power price & $14.50 \mathrm{USD} / \mathrm{kW}$-month (Note) \\
\hline Baseline GHG emission factor & As per Table II \\
\hline Transmission and distribution losses & $17.42 \%$ [1] (Note 2) \\
\hline Debt ratio & $0 \%$ (for initial evaluation) \\
\hline Revenue tax & $30 \%$ \\
\hline Target internal rate of return & $>10 \%$ \\
\hline & Notes: Estimated average for 2009-2023 period [1]. \\
\multicolumn{2}{|c|}{ 2. Including management process losses. }
\end{tabular}

\section{B. Hypothetical Case Study 1: Small Hydroelectric}

A $10 \mathrm{MW}$ installed capacity hydroelectric plant was considered in Bocas del Toro with a project life of 25 years. Various undergoing projects of this type and scale in Panama are envisioned to work on an energy contract for around $30 \%$ of the installed capacity, and complement with an additional power contract; so this scheme was assumed for this project.

The investment cost was estimated at 22 MMUSD based on the average construction cost on Table I, and operation and maintenance costs were assumed at 5.0 USD $/ \mathrm{kW}$-year [1]. Using RETScreen, a pre-tax internal rate of return of $13.1 \%$ was estimated. The post-tax internal rate of return was estimated at $11.8 \%$ when applying incentive number 4) on section 4-B of this paper. In contrast, if said incentive was not applied, the internal rate of return would have been $10.7 \%$.

\section{Hypothetical Case Study 2: Wind Farm}

A hypothetical $50 \mathrm{MW}$ installed capacity wind park was considered in Santiago, with a project life of 25 years. A $40 \%$ capacity factor was assumed (typical for wind speeds above $6 \mathrm{~m} / \mathrm{s}$, taking into account the best available turbine model). For this type of project, only an energy contract was assumed, consistent with [1], and a 5\% increase in the contracted energy price was considered as incentive.

The investment cost was estimated at 78 MMUSD based on the average construction cost on Table I, and annual operation and maintenance costs were assumed at 3.5 MMUSD. Using RETScreen, a pre-tax internal rate of return of $12.0 \%$ was estimated. The post-tax internal rate of return was estimated at $10.0 \%$ when applying incentive number 5) on section 4-B of this paper. In contrast, if said incentive was not applied, the internal rate of return would have been $8.9 \%$.

\section{Sensibility Analysis}

For the hydroelectric plant, the project ceases to be economically feasible when (all other assumptions equal) the investment cost exceeds $2,600 \mathrm{USD} / \mathrm{kW}$. On the other hand, a $10 \%$ reduction in the investment cost would increase the post-tax internal rate of return by $1.3 \%$.
For the wind farm, the project is already at the limit of economic feasibility with the originally assumed investment cost of $1,549 \mathrm{USD} / \mathrm{kW}$. On the other hand, a $10 \%$ reduction in the investment cost would also increase the post-tax internal rate of return by $1.3 \%$.

\section{E. Other Notes}

It is important to note that the previous evaluations do not consider the impact of economic benefits from carbon trading or adoption of a "spot" sales strategy, which could highly impact the project returns.

On the other hand, new energy sources not currently developed could be promoted if further official policies (other than the existing tax or energy price incentives) were adopted as part of a national strategy.

\section{Conclusion}

It can be concluded from this work that:

1) Hydro power is the only renewable currently used in the Panamanian power generation park and comprises most of the future CDM projects,

2) Wind power is the other renewable with most potential in Panama, with the second-largest number of CDM projects,

3) Solar, geothermal and peat resources are available in Panama but there are no current developments to include them as part of large-scale power generation.

4) Initial rough estimates of returns for hypothetical small hydroelectric and wind farm projects show internal rates of return of over $10 \%$ for both projects. Government incentives increased the post-tax internal rate of return by over $1 \%$ for the given assumptions; however, the project feasibility is dependent on specific site conditions that impact the investment cost (i.e. distance to transmission lines).

\section{References}

[1] ETESA, Plan de Expansión del Sistema Interconectado Nacional 2009-2023, Panamá, November $30^{\text {th }} 2009$.

[2] Environmental National Authority Climatic Change and Desertification Unit, CDM Portfolio, Panamá, 01/05/2010.

[3] Law No.6 of February 3rd 1997.

[4] Law N $\mathrm{N}^{\circ} 5$ of August 4th 2004.

[5] Resolution AN N ${ }^{\circ} 2700-E l e c$ of June $24^{\text {th }} 2009$.

[6] SWERA. Solar: annual average latitude tilt map at $40 \mathrm{~km}$ resolution for South America from NREL - July 2006. From: http://swera.unep.net/, retrieved on October $23^{\text {rd }} 2010$.

[7] Lahmeyer International, ETESA and UNDP. Estudio de Determinación del Potencial de la Energía Eólica en Panamá. 2006.

[8] ETESA, Potencial Geotérmico, http://www.etesa.com.pa/estudios.php?act=geotermico, retrieved on October 10th 2010.

[9] ETESA, Estudio de Turba, http://www.etesa.com.pa/estudios.php?act=turbt, retrieved on October 18th 2010.

[10] DA SILVA, Ysmael, Alberto Baumeister and Sebastiano Giardinella, Solar energy as option for power supply to houses and commercial buildings in Panama. Evaluation and conclusions", ICREPQ 2011. 